\title{
Otolith atlas of fish of the Sinos River
}

\author{
Bremm, CQ. and Schulz, UH.* \\ Laboratório de Ecologia de Peixes, Universidade do Vale do Rio dos Sinos - UNISINOS, \\ Avenida Unisinos, 950, CEP 93022-000, São Leopoldo, RS, Brazil \\ *e-mail: uwe@unisinos.br
}

Received June 29, 2012 - Accepted February 26, 2013 - Distributed May 31, 2014

(With 36 figures)

\begin{abstract}
Otoliths are calcium carbonate structures located in the inner ear of fish; they are responsible for hearing and balance. The inner ear has three pairs of otoliths: the lapilli, the sagittae and the asterisci. The sagittae otoliths are the largest and their format is species-specific. Because of their composition, otoliths can resist to the digestive tract of ichthyophagous species, and they can be used as an important tool for identifying species of fish found in stomach contents. The purpose of this work is to provide a photographic guide of the sagittae otoliths of the main fish species from the Sinos River. This atlas consists of photographs of the sagittae otoliths of 36 species belonging to 15 families distributed in five orders.
\end{abstract}

Keywords: photographic guide, sagittae, identification.

\section{Atlas de otólitos de peixes do Rio dos Sinos}

\section{Resumo}

Otólitos são estruturas formadas por cristais de carbonato de cálcio, localizadas no labirinto do ouvido interno dos peixes. São responsáveis pela audição e pelo equilíbrio. O ouvido interno possui três pares de otólitos, os lapilli, os sagittae e os asterisci. Os denominados sagittae são os maiores e seu formato é espécie-específico. Devido a sua composição os otólitos conseguem resistir ao trato digestivo das espécies ictiófagas, dessa maneira podem ser empregados como uma importante ferramenta para a identificação de espécies de peixes em trabalhos com conteúdos estomacais. O objetivo deste trabalho é a disponibilização de uma referência visual dos otólitos sagittae das principais espécies de peixes do Rio dos Sinos, para que possam servir de base para trabalhos com conteúdos estomacais de espécies ictiófagas. Este atlas é composto de fotografias dos otólitos sagittae de 36 espécies de 15 famílias distribuídas em cinco ordens.

Palavras chave: guia fotográfico, sagittae, identificação.

\section{Introduction}

Otoliths are paired structures composed of organic matter and calcium carbonate crystals, especially in the form of aragonite. These structures are located in the membranous labyrinth in the inner ear of fishes and are responsible for sound detection and maintenance of balance (Lecomte-Finiger, 1999; García et al., 2004; Payan et al., 2004; Popper et al., 2005).

The inner ear consists of three pairs of chambers, each containing an otolith. The otolith called lapilli occupies the utricular vestibule, the sagittae occupies the saccular and the asterisci the lagenar vestibule (Secor et al., 1991; Gomiero and Braga, 2007). Each pair is different in shape and appearance, and in most adult fish the sagittae are larger and have the largest morpholigical variability (Campana, 2004; Tuset et al., 2008).

Otoliths are formed from a primordial secreted by the inner ear, and are usually the first calcified structure formed during ontogenesis (Morales-Nin, 2000; Wright et al., 2002). The formation involves rhythmic variations in the deposition and size of the organic matrix fibre, which results in the formation of concentric layers of variable thickness
(Morales-Nin, 2000). These layers alternate in opaque and hyaline layers, representing periods of fast growth and slow growth, respectively; in temperate zones a pair of these layers consists of a year, and this set of layers is called annulus, and it is used for the age determination in years (Wright et al., 2002).

The characteristics, shape and growth pattern of otoliths are highly species specific and very similar between individuals (Frost, 1981; Hunt, 1992; Anguirre and Lombarte, 1999). Their chemical composition and microstructure are directly related to environmental conditions, so in addition to the identification of different species it is possible to differentiate between stocks (Lecomte-Finiger, 1999).

Furthermore, otoliths can resist the passage through the digestive tract of ichthyophagous species because of their low degradability. Thus they have been used as an important tool for studies of stomach contents (Frost, 1981; Gomiero and Braga, 2007).

In Brazil there are only otolith catalogs of marine fish, such the work of Correa and Vianna that in 1992/93 described the otoliths of the family Scianidae from the 
coast of Paraná. The same study lists only five previous studies of isolated morphological descriptions. In 1995 Lemos et al. (1995a, b), published two catalogs, which describe the otoliths of the family Engraulidade and Cupleidae, both of the coast of Paraná.

The purpose of this work is to provide a photographic guide of the sagittae otoliths of the most common fish species from the Sinos river. The intention is to provide a visual reference which may serve as basis for studies of stomach contents of ichthyophagous species.

\section{Materials and Methods}

The fish used in this investigation were sampled in different projects of the Laboratory of Fish Ecology UNISINOS. All the fish were captured in the Sinos River by electrofishing or gill nets (meshes $15 \mathrm{~mm}$ to $60 \mathrm{~mm}$ ) between the years of 2006 and 2007. All individuals were measured (standard length, SL), weighed and stored on ice until the removal of otoliths. Only the pair of sagittae was removed.

After removal, the otoliths were washed in water and stored in glass tubes that had remained open for about 15 days to ensure that the otoliths completely dried.

Otoliths were measured (otolith length - OL) and photographed in pairs in a way that both sides were visible. The photographs were taken with a Leica Stereo Macroscope attached to a video camera, connected to a computer with the image analysis program Leica Application Suite v3.7.

\section{Results}

In this work we photographed the otoliths of 36 species from 15 families distributed in five orders. Four of these species do not belong to the native fish community of the Sinos river basin. Two are exotic (Micropterus salmoides and Orechromis niloticus), one is invasive (Pachyurus bonariensis) and another one allochthonous (Piaractus mesopotamicus) (Leal et al., 2009).

\section{Characiformes}

Anostomidae (Figure 1 and 2)

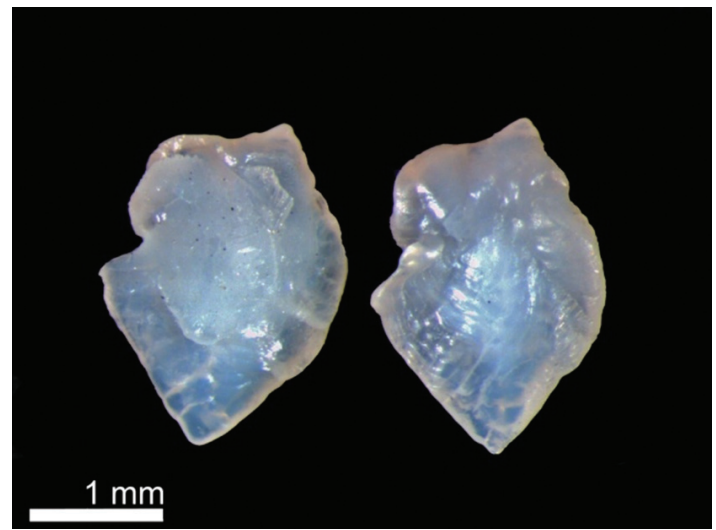

Figure 1. Sagitta otoliths of Leporinus obtusidens (Valenciennes, 1837) (Fish Length $=18 \mathrm{~cm}$; Otolith Length= $2.6 \mathrm{~mm})$.

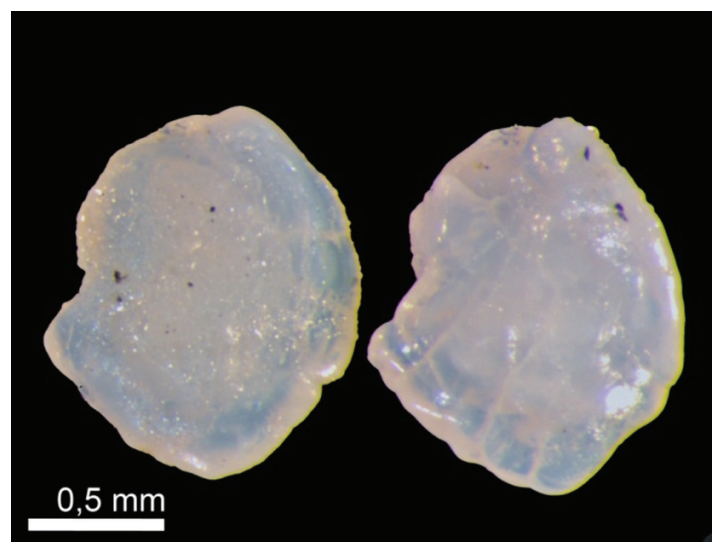

Figure 2. Sagitta otoliths of Schizodon jacuiensis (Bergmann, 1988) $(\mathrm{FL}=7.8 \mathrm{~cm} ; \mathrm{OL}=1.46 \mathrm{~mm})$.

Characidae (Figure 3-10)

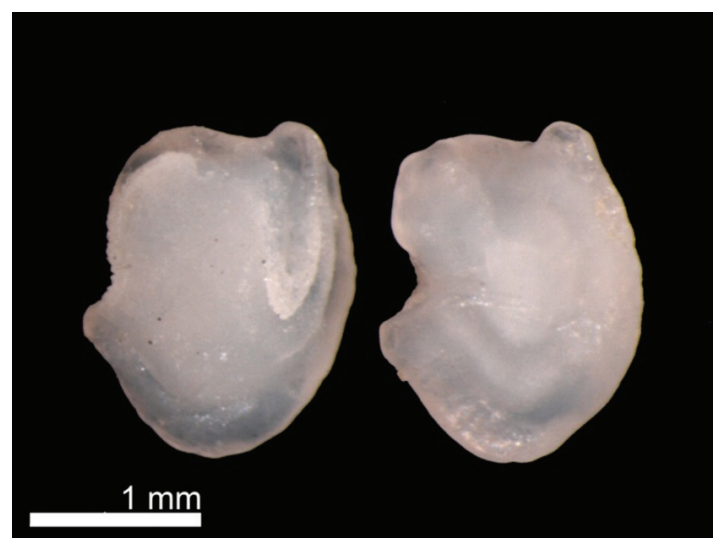

Figure 3. Sagitta otoliths of Astyanax fasciatus (Cuvier, 1819) $(\mathrm{FL}=11.4 \mathrm{~cm} ; \mathrm{OL}=1.97 \mathrm{~mm})$.

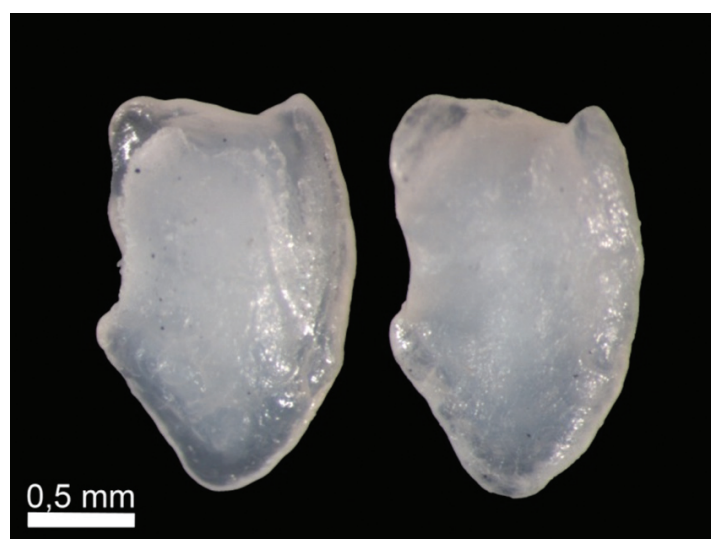

Figure 4. Sagitta otoliths of Astyanax jacuhiensis (Cope, 1894) $(\mathrm{FL}=9.4 \mathrm{~cm} ; \mathrm{OL}=1.88 \mathrm{~mm})$. 


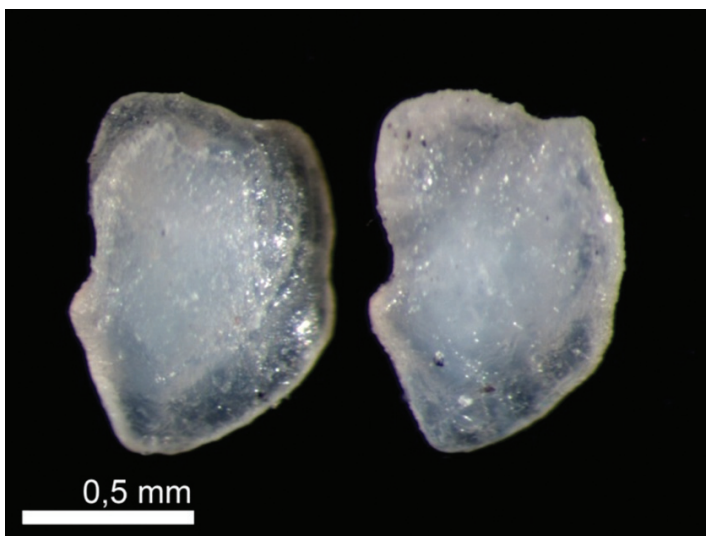

Figure 5. Sagitta otoliths of Hyphessobrycon luetkenii (Boulenger, 1887) $(\mathrm{FL}=5.0 \mathrm{~cm} ; \mathrm{OL}=1.01 \mathrm{~mm})$.

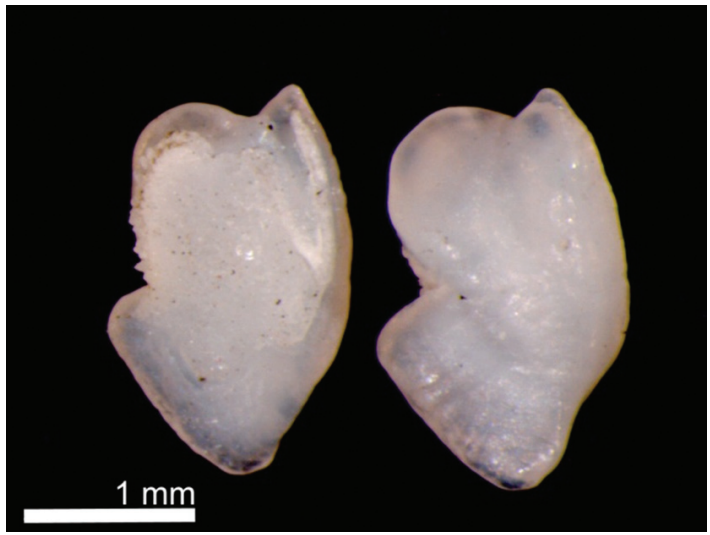

Figure 6. Sagitta otoliths of Oligosarcus robustus (Menezes, 1969) $(\mathrm{FL}=10 \mathrm{~cm} ; \mathrm{OL}=2.36 \mathrm{~mm})$.

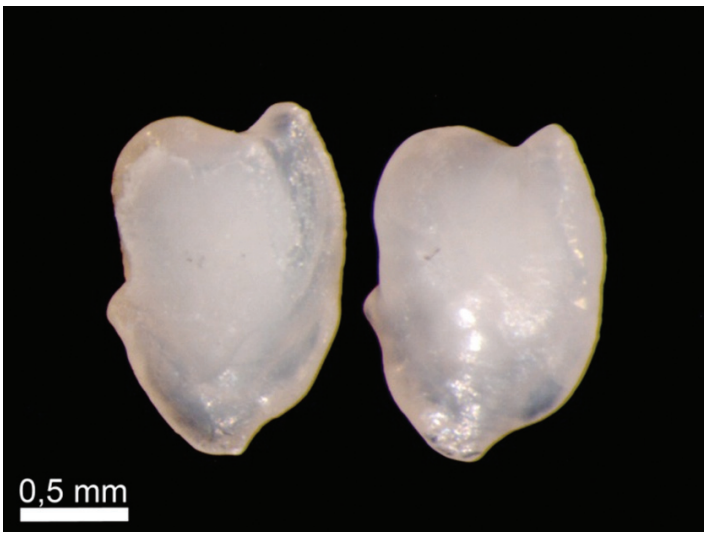

Figure 7. Sagitta otoliths of Oligosarcus jenynsii (Günther, 1864) $(\mathrm{FL}=12.2 \mathrm{~cm} ; \mathrm{OL}=1.66 \mathrm{~mm})$.

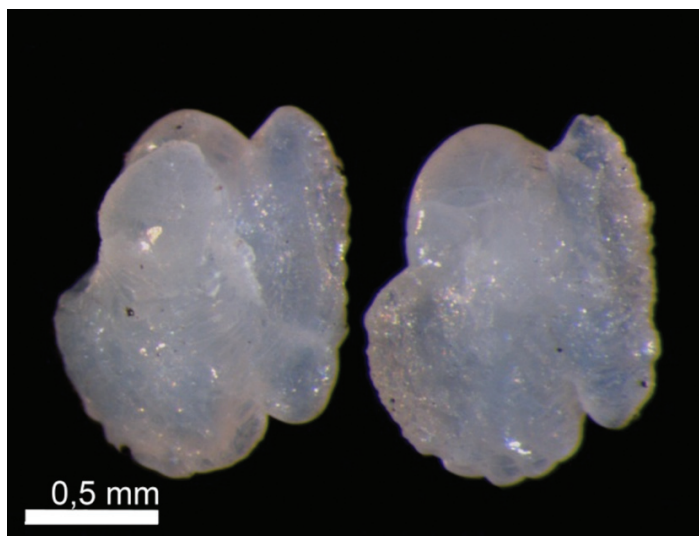

Figure 8. Sagitta otoliths of Piaractus mesopotamicus (Holmberg, 1887) $(\mathrm{FL}=5.5 \mathrm{~cm} ; \mathrm{OL}=1.32 \mathrm{~mm})$.

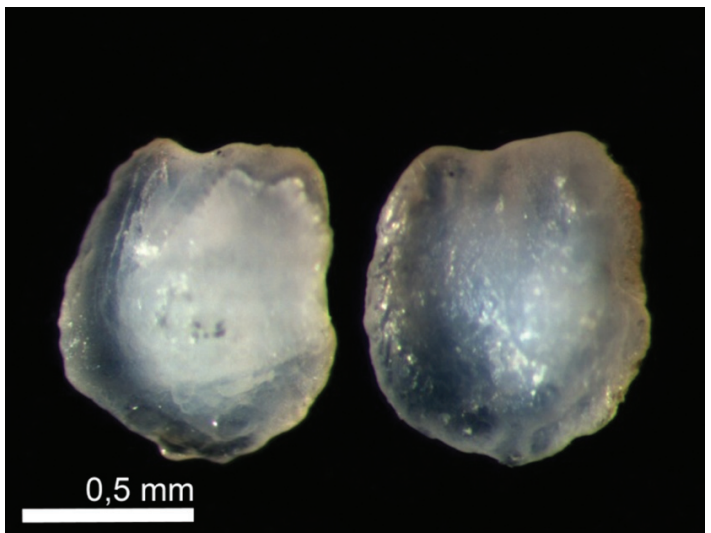

Figure 9. Sagitta otoliths of Pseudocorynopoma doriae (Perugia, 1891) $(\mathrm{FL}=5.7 \mathrm{~cm} ; \mathrm{OL}=0.92 \mathrm{~mm})$.

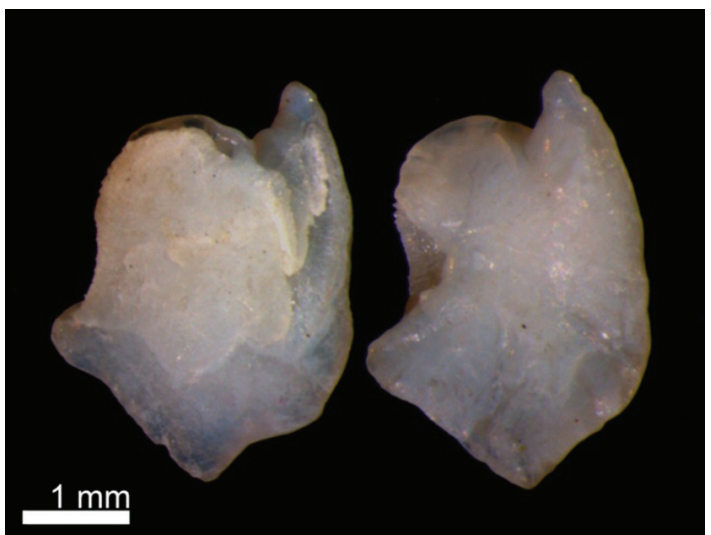

Figure 10. Sagitta otoliths of Salminus brasiliensis (Cuvier, 1816) $(\mathrm{FL}=33.4 \mathrm{~cm} ; \mathrm{OL}=3.73 \mathrm{~mm})$. 
Curimatidae (Figure 11)

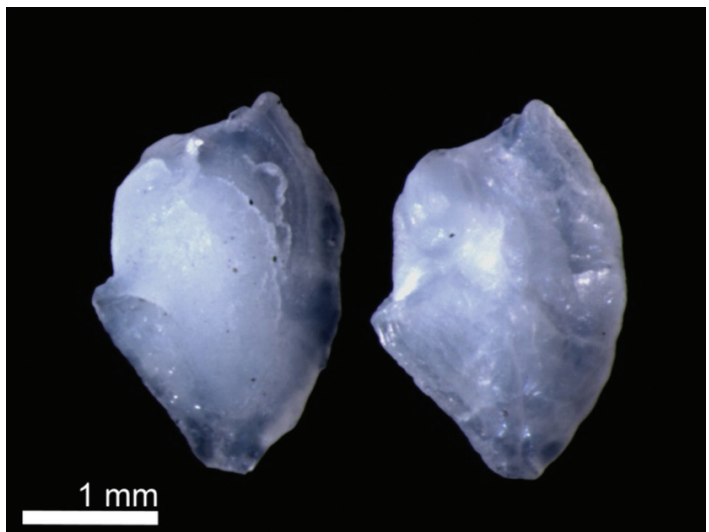

Figure 11. Sagitta otoliths of Cyphocharax voga (Hensel, 1870) $(\mathrm{FL}=13.3 \mathrm{~cm} ; \mathrm{OL}=2.85 \mathrm{~mm})$.

\section{Erythrinidae (Figure 12)}

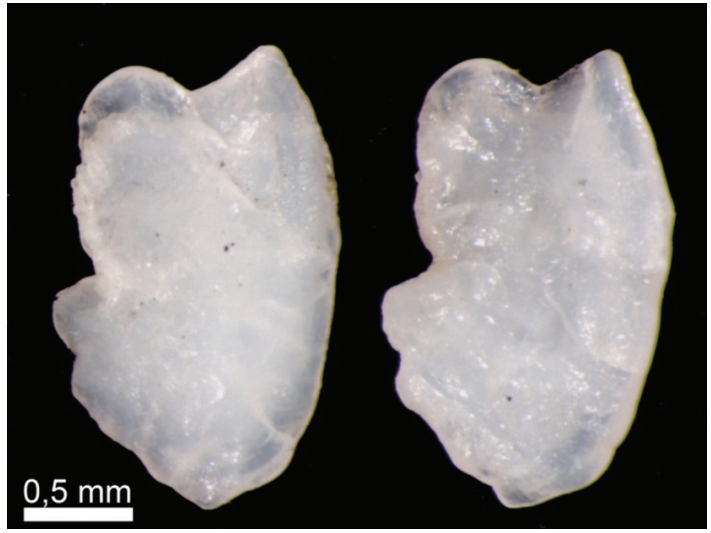

Figure 12. Sagitta otoliths of Hoplias malabaricus (Bloch, 1794) $(\mathrm{FL}=14.3 \mathrm{~cm} ; \mathrm{OL}=2.13 \mathrm{~mm})$.

\section{Prochilodontidae (Figure 13)}

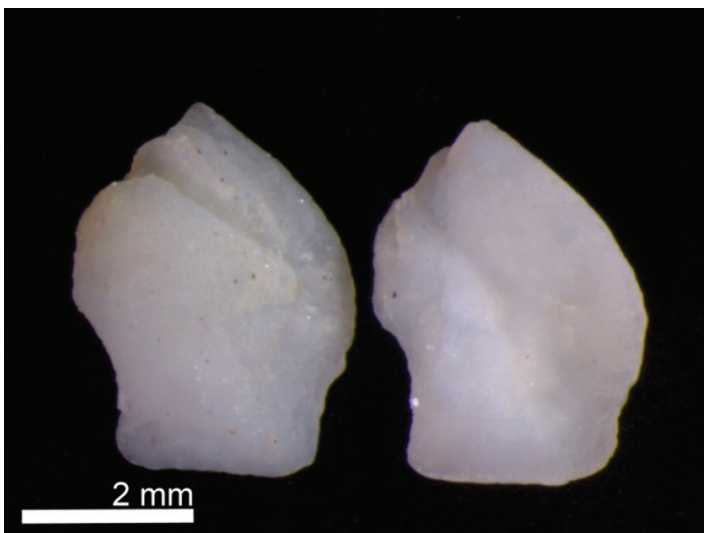

Figure 13. Sagitta otoliths of Prochilodus lineatus (Valenciennes, 1837) $(\mathrm{FL}=29.5 \mathrm{~cm} ; \mathrm{OL}=4.66 \mathrm{~mm})$.

\section{Clupeiformes}

Engraulididae (Figure 14)

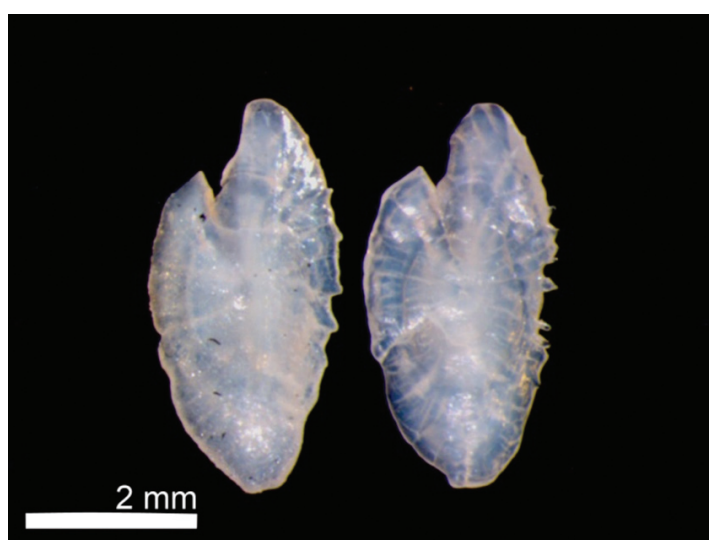

Figure 14. Sagitta otoliths of Lycengraulis grossidens (Spix \& Agassiz, 1829) $(\mathrm{FL}=18 \mathrm{~cm} ; \mathrm{OL}=4.64 \mathrm{~mm})$.

\section{Gymnotiformes}

Gymnotidae (Figure 15)

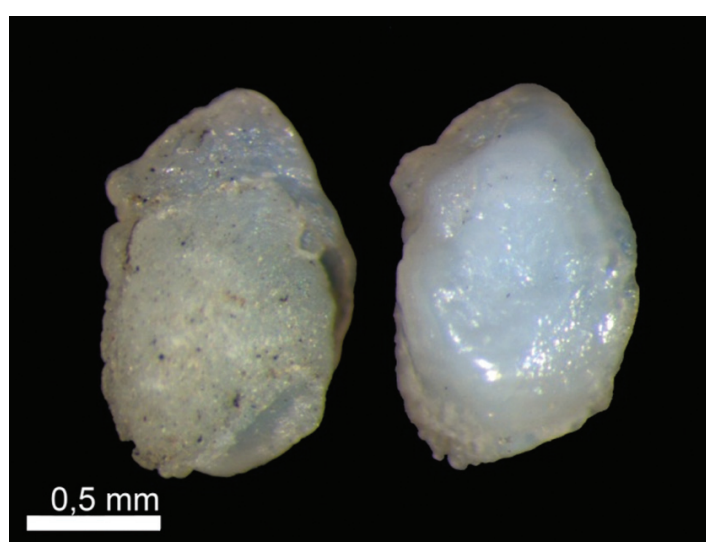

Figure 15. Sagitta otoliths of Gymnotus carapo (Linnaeus, 1758) $(\mathrm{FL}=25 \mathrm{~cm} ; \mathrm{OL}=1.50 \mathrm{~mm})$.

\section{Perciformes}

\section{Centrarchidae (Figure 16)}

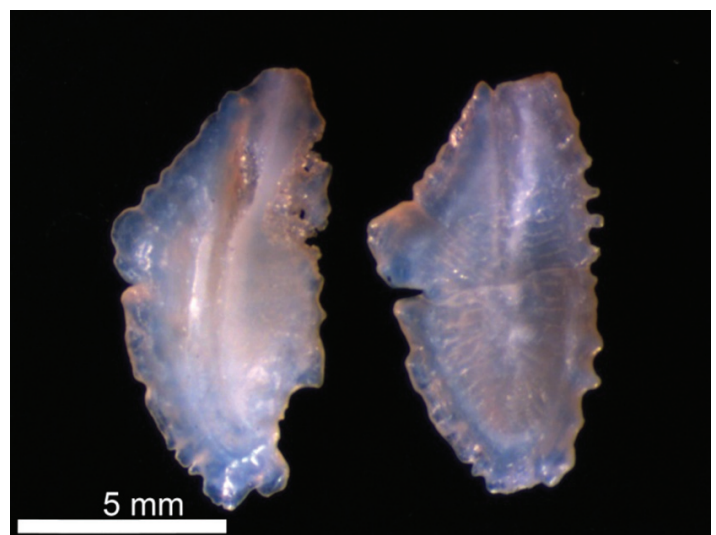

Figure 16. Sagitta otoliths of Micropterus salmoides (Lacepède, 1802) $(\mathrm{FL}=27.1 \mathrm{~cm} ; \mathrm{OL}=9.92 \mathrm{~mm})$. 
Cichlidae (Figure 17-24)

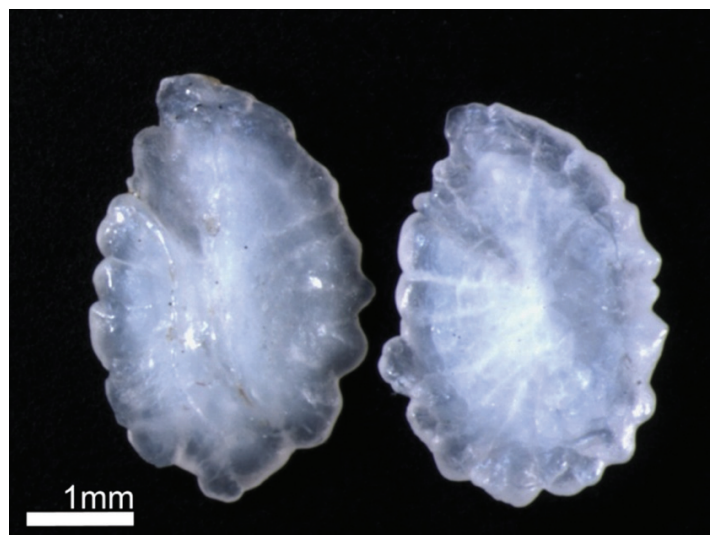

Figure 17. Sagitta otoliths of Australoheros facetus (Jenyns, 1842) $(\mathrm{FL}=9.9 \mathrm{~cm} ; \mathrm{OL}=4.04 \mathrm{~mm})$.

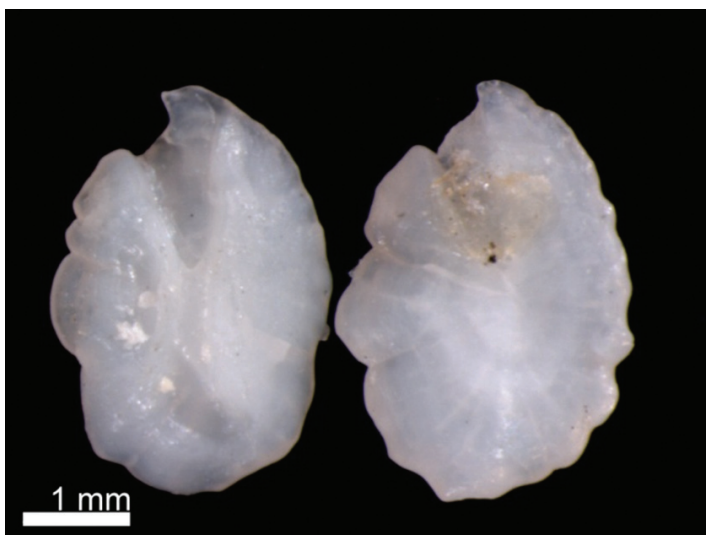

Figure 18. Sagitta otoliths of Cichlasoma portalegrense (Hensel, 1870) $(\mathrm{CP}=9 \mathrm{~cm} ; \mathrm{CO}=3.72 \mathrm{~mm})$.

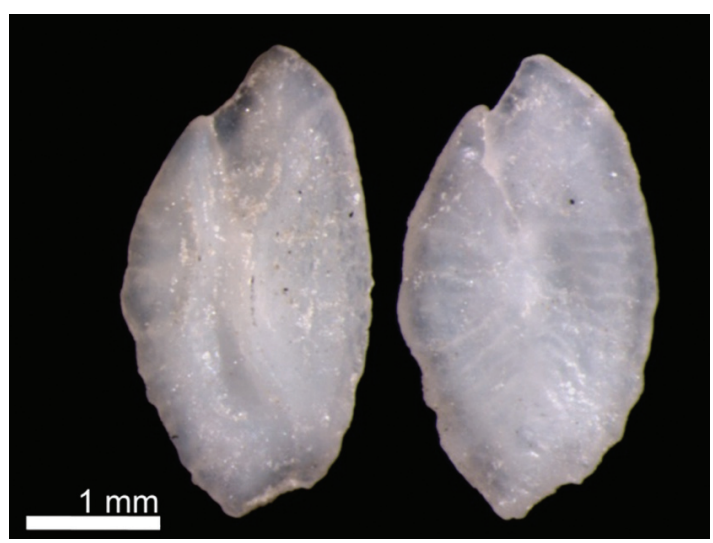

Figure 19. Sagitta otoliths of Crenicichla lepidota (Heckel, 1840) $(\mathrm{FL}=7.2 \mathrm{~cm} ; \mathrm{OL}=3.61 \mathrm{~mm})$.

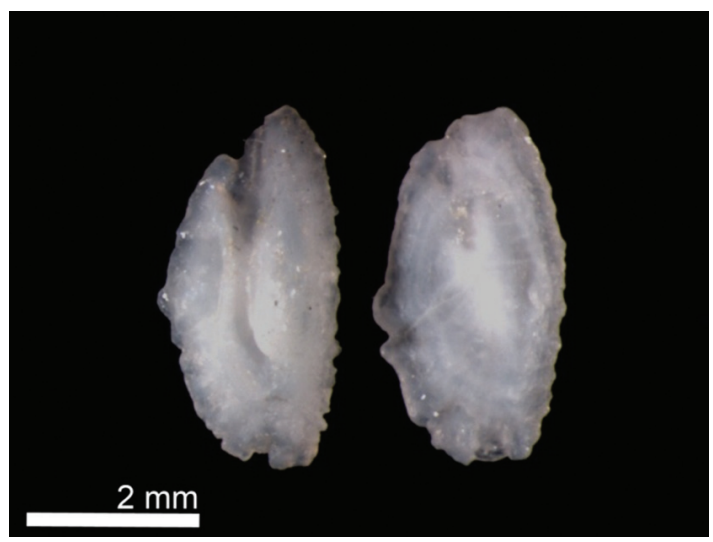

Figure 20. Sagitta otoliths of Crenicichla punctata (Hensel, 1870) $(\mathrm{FL}=10.9 \mathrm{~cm} ; \mathrm{OL}=4.25 \mathrm{~mm})$.

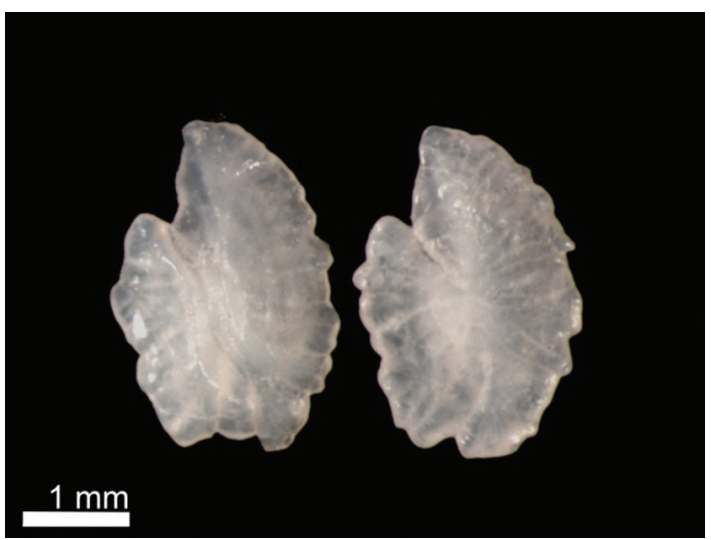

Figure 21. Sagitta otoliths of Geophagus brasiliensis (Quoy \& Gaimard, 1824) $(\mathrm{FL}=7.4 \mathrm{~cm} ; \mathrm{OL}=3.13 \mathrm{~mm})$.

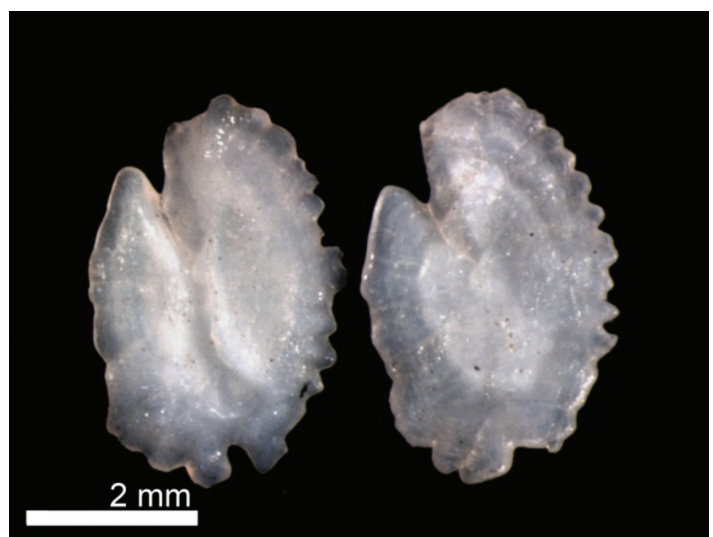

Figure 22. Sagitta otoliths of Gymnogeophagus gymnogenys (Hensel, 1870) $(\mathrm{FL}=12 \mathrm{~cm} ; \mathrm{OL}=4.60 \mathrm{~mm})$. 


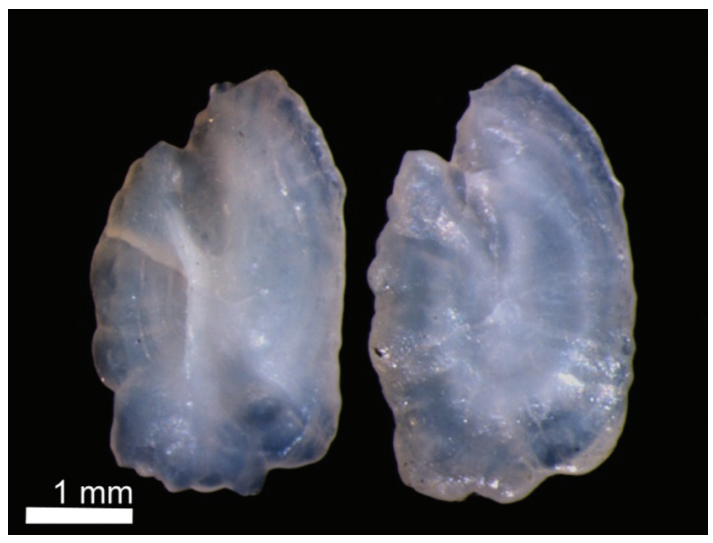

Figure 23. Sagitta otoliths of Gymnogeophagus labiatus (Hensel, 1870) $(\mathrm{FL}=12.5 \mathrm{~cm}$; $\mathrm{OL}=3.90 \mathrm{~mm})$.

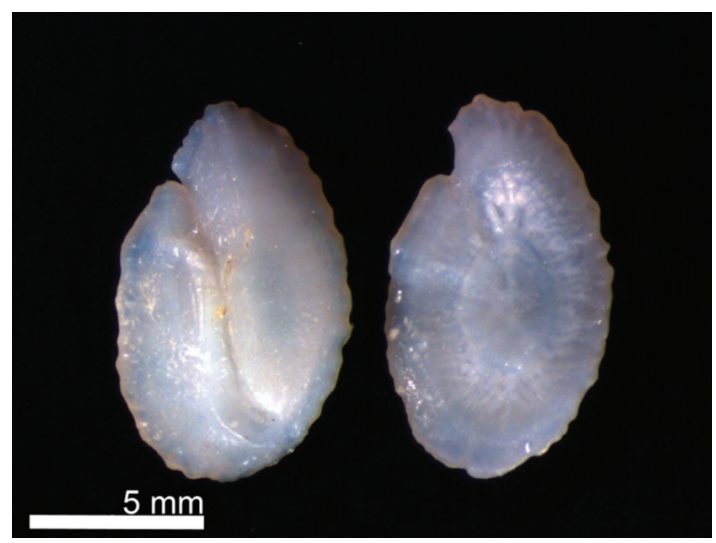

Figure 24. Sagitta otoliths of Oreochromis niloticus (Linnaeus, 1758) $(\mathrm{FL}=24.9 \mathrm{~cm} ; \mathrm{OL}=10 \mathrm{~mm})$.

\section{Sciaenidae (Figure 25)}

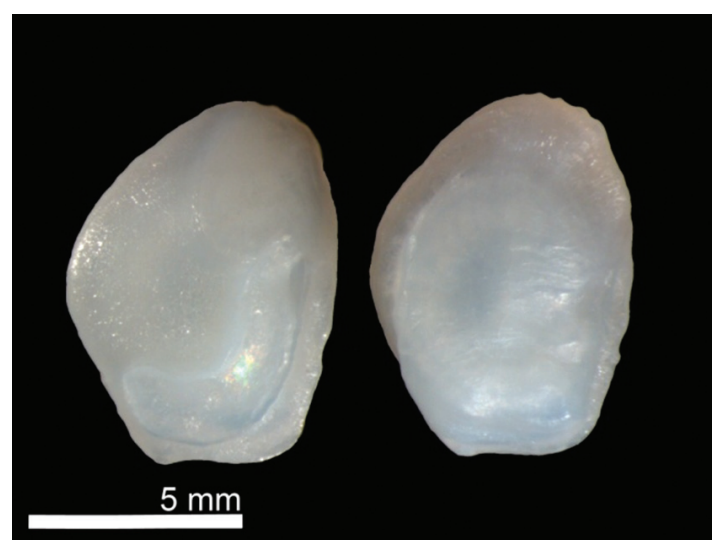

Figure 25. Sagitta otoliths of Pachyurus bonariensis (Steindachner, 1879) $(\mathrm{FL}=14 \mathrm{~cm} ; \mathrm{OL}=8.31 \mathrm{~mm})$.

\section{Siluriformes}

Callichthyidae (Figure 26-28)

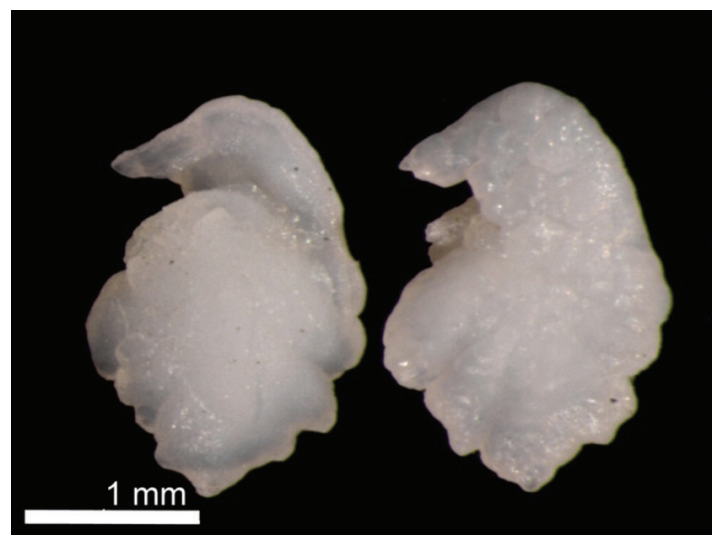

Figure 26. Sagitta otoliths of Callichthys callichthys (Linnaeus, 1758) $(\mathrm{FL}=10.7 \mathrm{~cm} ; \mathrm{OL}=2.33 \mathrm{~mm})$.

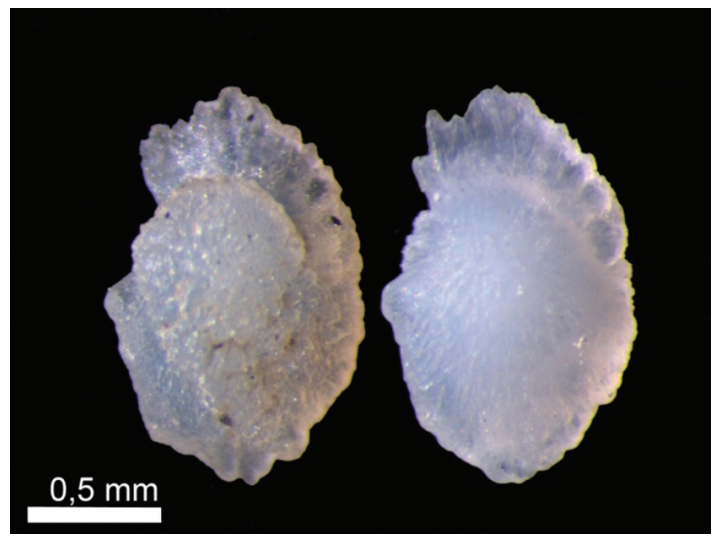

Figure 27. Sagitta otoliths of Corydoras paleatus (Jenyns, 1842) $(\mathrm{FL}=5.6 \mathrm{~cm} ; \mathrm{OL}=1.46 \mathrm{~mm})$.

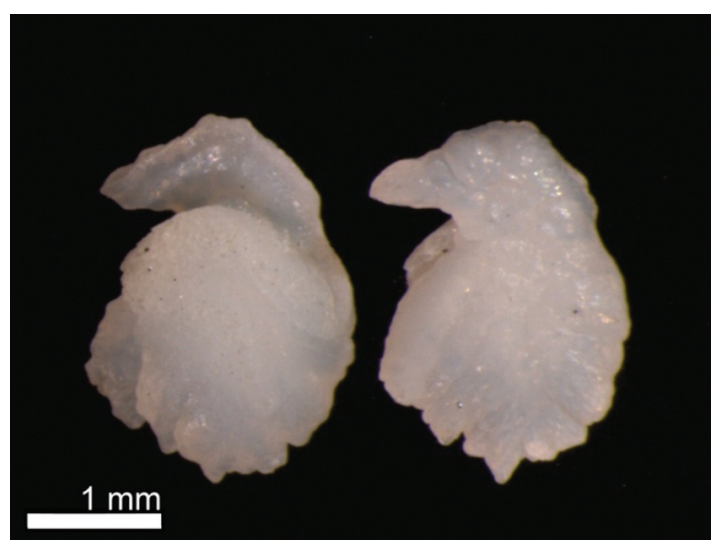

Figure 28. Sagitta otoliths of Hoplosternum littorale (Hancock, 1828) $(\mathrm{FL}=15.4 \mathrm{~cm} ; \mathrm{OL}=2.62 \mathrm{~mm})$. 
Heptapteridae (Figure 29 and 30)

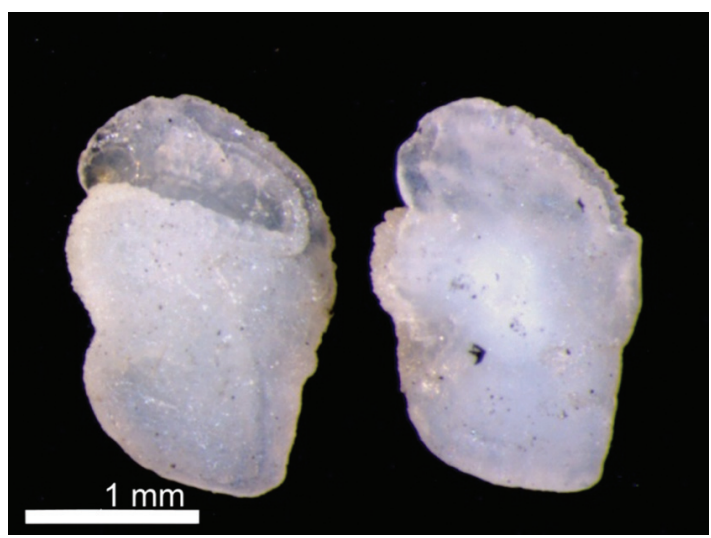

Figure 29. Sagitta otoliths of Pimelodella australis (Eigenmann, 1917) $(\mathrm{FL}=11.6 \mathrm{~cm} ; \mathrm{OL}=2.52 \mathrm{~mm})$.

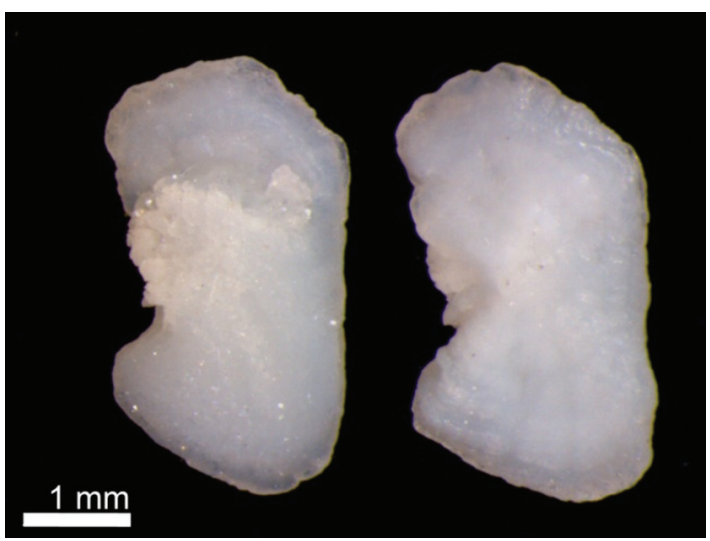

Figure 30. Sagitta otoliths of Rhamdia quelen (Quoy \& Gaimard, 1824) $(\mathrm{FL}=11.2 \mathrm{~cm} ; \mathrm{OL}=4.15 \mathrm{~mm})$.

Loricariidae (Figure 31-33)

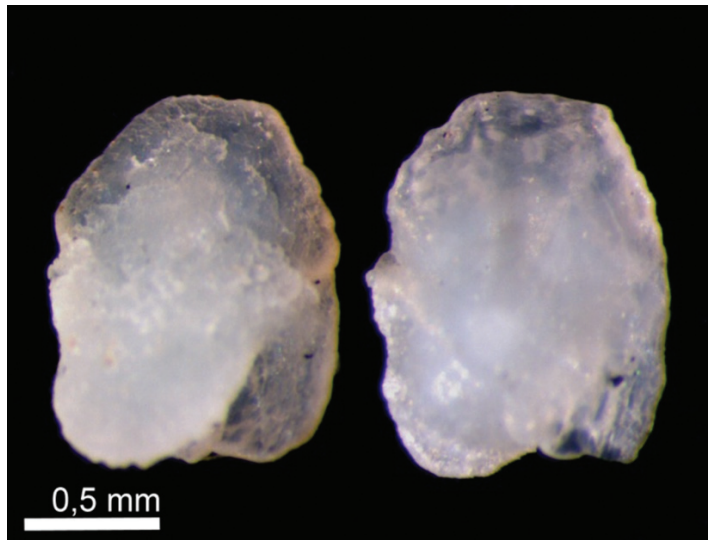

Figure 31. Sagitta otoliths of Hemiancistrus punctulatus (Cardoso \& Malabarba, 1999) ( $\mathrm{FL}=20.4 \mathrm{~cm} ; \mathrm{OL}=1.39 \mathrm{~mm})$.

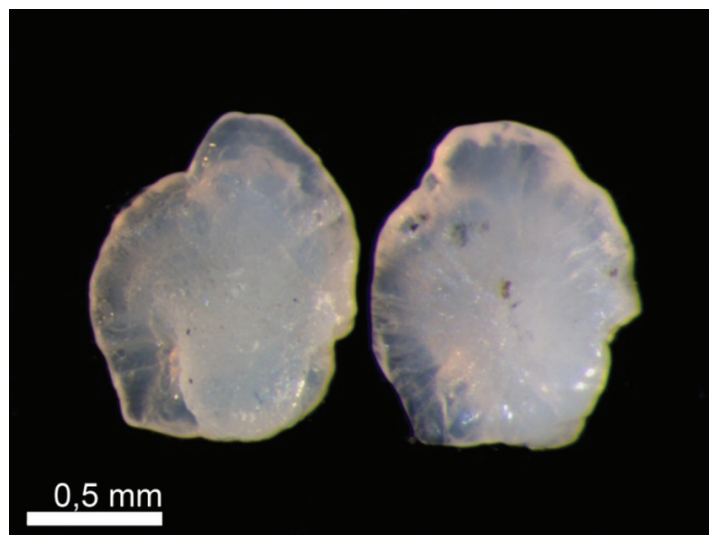

Figure 32. Sagitta otoliths of Hypostomus commersoni (Valenciennes, 1836) $(\mathrm{FL}=11.7 \mathrm{~cm} ; \mathrm{OL}=1.17 \mathrm{~mm})$.

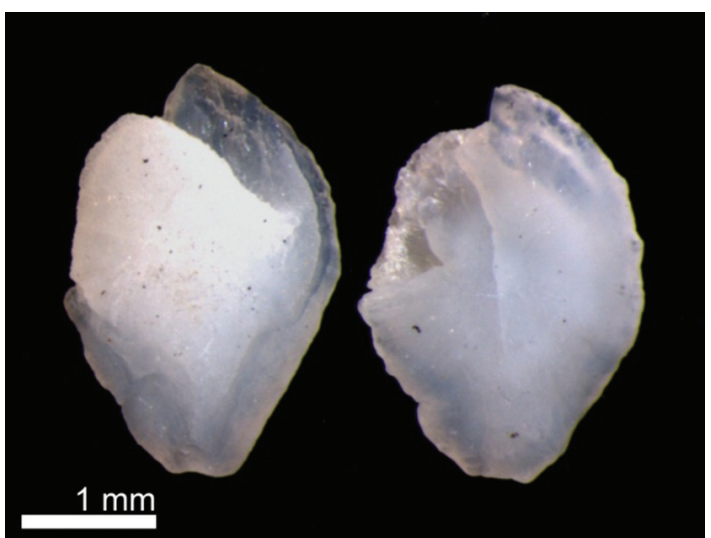

Figure 33. Sagitta otoliths of Loricariichthys anus (Valenciennes, 1835) $(\mathrm{FL}=38.4 \mathrm{~cm} ; \mathrm{OL}=2.97 \mathrm{~mm})$.

Pimelodidae (Figure 34 and 35)

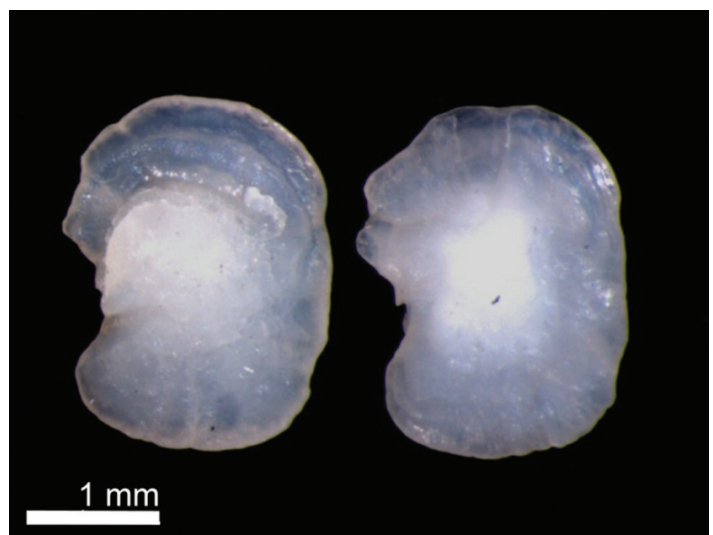

Figure 34. Sagitta otoliths of Parapimelodus nigribarbis (Boulenger, 1889) $(\mathrm{FL}=12.7 \mathrm{~cm} ; \mathrm{OL}=2.71 \mathrm{~mm})$. 


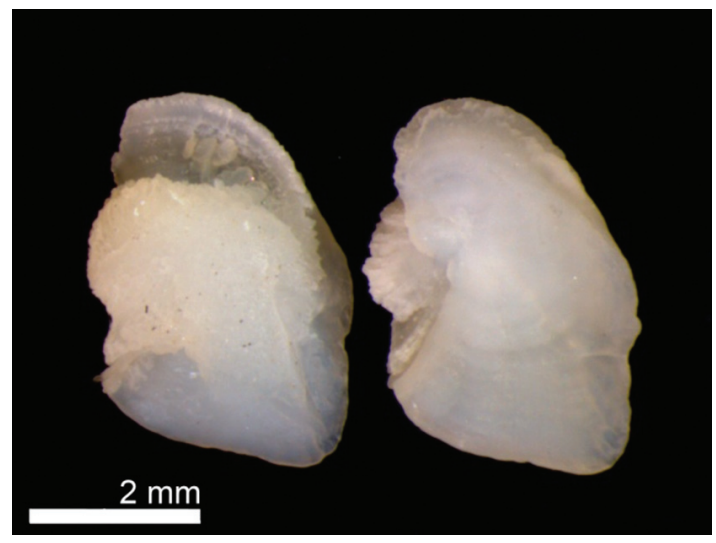

Figure 35. Sagitta otoliths of Pimelodus maculatus (Lacepède, 1803) $(\mathrm{FL}=29.3 \mathrm{~cm} ; \mathrm{OL}=4.37 \mathrm{~mm})$.

\section{Synbranchiformes}

Synbranchidae (Figure 36)

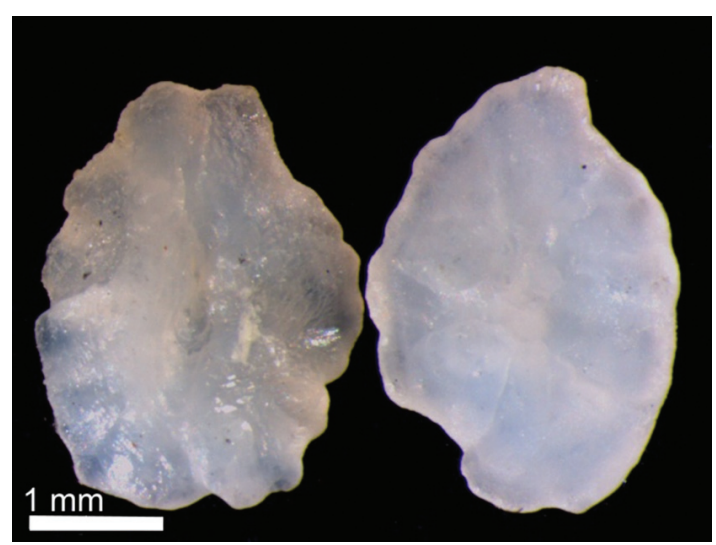

Figure 36. Sagitta otoliths of Synbranchus marmoratus (Bloch, 1795) $(\mathrm{FL}=35 \mathrm{~cm} ; \mathrm{OL}=3.27 \mathrm{~mm})$.

\section{Discussion}

As reported by Torno (1976) species of the same genus may have very similar otoliths. In this study it was shown that Gymnogeophagus gymnogenys and G. labiatus and also Crenicichla lepidota and C. puntacta have otoliths that are almost not differentiable.

When considering families, it was possible to identify common features in their morphology. In the families Cichlidae and Characidae, for example, the shape of otolith is very similar in all species. Corrêa and Vianna (1992/93) reported the existence of such common features within families, characteristics like common shape, location of the sulcus, form of the ostium and otolith tail.

When using otoliths for species identification it should be remembered that the shape and size of the otolith may differ in different life stages of individuals. Most larval stages do not display a specific shape. The final shape is defined only in the juvenile stage (Campana, 2004).
The similarity of otolith shape may impede the exact identification of species in some cases (Tuset et al., 2008). However, with this atlas it may be possible to have a handy visual reference for an easy identification of the diet of ichthyophagous species of the Sinos river and also adjacent basins with similar fish assemblies.

\section{References}

ANGUIRRE, H. and LOMBARTE, A., 1999. Ecomorphological comparisons of sagittae in Mullus barbatus and M. surmuletus. Journal of Fish Biology, vol. 55, no. 1, p. 105-114.

CAMPANA, SE., 2004. Photographic atlas of fish otoliths of the Northwest Atlantic Ocean. Ottawa: NRC Research Press. 284 p. CORRÊA, MFM. and VIANNA, MS., 1992/93. Catálogo de otólitos de Scianidae (Osteichthyes- Perciformes) do litoral do Estado do Paraná. Nerítica, vol. 7, no. 1-2, p. 109-117.

FROST, KJ., 1981. Descriptive key to the otoliths of gadid fishes of the Bering, Chukchi, and Beaufort Seas. Artic, vol. 34, no. 1, p. $55-59$.

GARCÍA, MRH., PÉREZ, JAM., LÓPEZ, TAB. and RODRÍGUEZ, JMR., 2004. Descripción morfológica de los otólitos de las familias Engraulidae, Haemulidae y Achiridae del sistema estuarino de Tecolutla. Veracruz. Revista de Zoología, vol. 15, p. 7-13.

GOMIERO, LM. and BRAGA, FMS., 2007. Descrição dos otólitos de tucunarés (Cichla sp. e Cichla monoculus) no reservatório da hidrelétrica de Volta Grande (SP-MG). Ciência Animal Brasileira, vol. 8 , no. 1 , p. 119-126.

HUNT, JJ., 1992. Morphological characteristics of otolith for selected fish in the northwest Atlantic. Journal of Northwest Atlantic Fishery Science, vol. 13, p. 63-75. http://dx.doi.org/10.2960/J.v13.a5.

LEAL, ME., BREMM, CQ. and SCHULZ, UH., 2009. Lista da ictiocenose da bacia do Rio dos Sinos, Sul do Brasil. Boletim do Instituto de Pesca, vol. 35, p. 307-317.

LECOMTE-FINIGER, R., 1999. L'otolithe : la « boîte noire » des Téléostéens. L'Annee Biologique, vol. 38, no. 2, p. 107-122. http://dx.doi.org/10.1016/S0003-5017(99)80029-4.

LEMOS, PHB., CORRÊA, MFM. and PINHEIRO, PC., 1995a. Catálogo de otólitos de Engraulidae (Clupeiformes- Osteichthyes) do litoral do Paraná, Brasil. Arquivos Biológicos Tecnológicos, vol. 38 , no. 3, p. 731-745.

LEMOS, PHB., CORRÊA, MFM. and PINHEIRO, PC., 1995b. Catálogo de otólitos de Cupleidae (Clupeiformes- Osteichthyes) do litoral do Paraná, Brasil. Arquivos Biológicos Tecnológicos, vol. 38 , no. 3 , p. $747-759$.

MORALES-NIN, B., 2000. Review of the growth regulation processes of otolith daily increment formation. Fisheries Research, vol. 46, no. 1-3, p. 53-67. http://dx.doi.org/10.1016/S01657836(00)00133-8.

PAYAN, P., DE PONTUAL, H., BOEUF, G. and MAYERGOSTAN, N., 2004. Endolymph chemistry and otolith growth in fish. Comptes Rendus Palevol, vol. 3, no. 6-7, p. 535-547. http:// dx.doi.org/10.1016/j.crpv.2004.07.013.

POPPER, AN., RAMCHARITAR, J. and CAMPANA, SE., 2005. Why otoliths? Insights from inner ear physiology and fisheries biology. Marine \& Freshwater Research, vol. 56, no. 5, p. $497-$ 504. http://dx.doi.org/10.1071/MF04267. 
SECOR, DH., DEAN, JM. and LABAN, EH., 1991. Manual for otolith removal and preparation for microstructural examination. Columbia: Electric Power Research Institute and Belle W. Baruch Institute for Marine Biology and Coastal Research. 85 p.

TORNO, MF., 1976. Descripción e comparación de los otolitos de algunas familias de peces de la plataforma Argentina. Revista del Museo Argentino de Ciencias Naturales. Bernardino Rivadavia, vol. 12 , no. 4 , p. $25-44$
TUSET, VM., LOMBARTE, A. and ASSIS, CA., 2008. Otolith atlas for the western Mediterranean, north and central eastern Atlantic. Scientia Marina, vol. 72, no. S1, p. 7-198. http://dx.doi. org/10.3989/scimar.2008.72s17.

WRIGHT, PJ., PANFILI, J., MORALES-NIN, B. and GEFFEN, J.,2002. Types of calcified structures: Otoliths. In PANFILI, J., PONTUAL, H., TROADEC, H. and WRIGHT, PJ. (Ed.). Manual of fish sclerochronology. Brest: Ifremer-ird, p. 31-57. 